\title{
Plant diversity, structure and composition of vegetation around Barumun Watershed, North Sumatra, Indonesia
}

\author{
RIDAHATI RAMBEY ${ }^{1,4, \boldsymbol{v}}$, ARIDA SUSILOWATI ${ }^{1,4}$, AHMAD BAIQUNI RANGKUTI ${ }^{1,4}$, ONRIZAL ONRIZAL $^{1}$, \\ DESRITA $^{2}$, RIO ARDI ${ }^{5}$, ADRIAN HARTANTO ${ }^{3}$ \\ ${ }^{1}$ Department of Forestry, Faculty of Forestry, Universitas Sumatera Utara. Jl. Tridharma Ujung No. 1, Kampus USU, Medan 20155, North Sumatra, \\ Indonesia. Tel./fax.: +62-61-8220605, `email: ridahati.rambey@usu.ac.id \\ ${ }^{2}$ Department of Aquatic Resources Management, Faculty of Agriculture, Universitas Sumatera Utara. Jl. Prof. A. Sofian No. 3, Kampus USU, Medan \\ 20155, North Sumatra, Indonesia \\ ${ }^{3}$ Department of Biology, Faculty of Mathematics and Natural Sciences, University of Sumatera Utara. Jl. Bioteknologi No. 1 Kampus USU, Medan \\ 20155, North Sumatra, Indonesia \\ ${ }^{4}$ JATI - Sumatran Forestry Analysis Study Center. Jl. Tri Dharma Ujung No. 1, Kampus USU, Medan 20155, North Sumatra, Indonesia \\ ${ }^{5}$ Yayasan Orangutan Sumatera Lestari - Orangutan Information Centre. Jl. Bunga Sedap Malam 18C No. 10, Medan 20131, North Sumatra, Indonesia
}

Manuscript received: 24 June 2021. Revision accepted: 16 July 2021.

\begin{abstract}
Rambey R, Susilowati A, Rangkuti AB, Onrizal O, Desrita, Ardhi R, Hartanto A. 2021. Plant diversity, structure and composition of vegetation around Barumun Watershed, North Sumatra, Indonesia. Biodiversitas 22: 3250-3256. Watershed ecosystem plays an important role in water and soil conservation which is supported by vegetation around watershed. As such, vegetation analysis is beneficial to assess the current state of watershed vegetation and monitor future changes. Barumun Watershed, located in South Labuhanbatu District, North Sumatra Province, Indonesia, is under threat due to habitat degradation and land conversion for plantation and agriculture. This research aimed to investigate the diversity, structure and composition of vegetation in the Barumun River including its smaller streams (rivulets). Data were collected using a combination of line transect and quadratic plots arranged systematically. The total observation plots were 48 plots, consisting of 24 plots in Barumun River, 12 plots in Tasik Rivulet and 12 plots in Titi Kembar Rivulet. The results documented a total of 51 plants in the studied sites in Barumun Watershed in which 37 species were found in Barumun River, 20 species in Tasik Rivulet and 17 species in the Titi Kembar Rivulet. Plant species consisted of several habitus including herbs, palms, shrubs, climbers and trees. The trees consisted of 22 species $(43.13 \%)$, herbs 22 species (43.13\%), climbers 3 species (5.88\%), shrubs two species (3.92\%), and palm two species $(3.92 \%)$. The highest Importance Value Index (IVI) for tree community was recorded in the Barumun River from Hevea brasiliensis (108.28), followed by Cryptocarya sp. (123.24) in the Titi Kembar Rivulet. In addition, the highest IVI for pole, sapling, seedling, and shrub was recorded from Muntingia calabura (Barumun River), Nauclea orientalis (Tasik Rivulet), Psychotria viridiflora (Tasik Rivulet), and Calamus axillaris (Titi Kembar Rivulet), respectively. The plant diversity in Barumun Watershed was categorized from low to moderate level of richness.
\end{abstract}

Keywords: Barumun river, community structure, Importance Value Index, riparian vegetation, species diversity

\section{INTRODUCTION}

Watershed ecosystem is an ecosystem unit from the largest river basins to the smaller streams (or rivulet) that holds important ecological roles to human community and other living organisms. Besides its function as physical protection of the hydrological systems, watersheds also conserve soils by controlling erosion and may prevent natural disasters such as floods and landslides. Therefore, watershed needs to be managed properly to maintain its sustainability (Halengkara et al. 2012).

Vegetation serves as an integral component in the soil and atmospheric systems (Piao et al. 2015; Liu et al. 2020; Tian et al. 2021). In general, the role of vegetation in an ecosystem is maintaining the balance of carbon dioxide and oxygen concentration in the air, improving the physical, chemical and biological properties of soil, regulating groundwater systems and other beneficial roles (Indriyanto 2006; Basrowi et al. 2018). The existence of undisturbed vegetation in a landscape will positively impact the balance of the ecosystem with greater impacts within a region.
Accordingly, there is a strong inter-relationship between watershed ecosystem and the vegetation that occurred there in the context of watershed.

Indonesia is known as the mega biodiversity country due the large number of species that live in a broad range of ecosystems, including watershed ecosystems. One of the watersheds in Indonesia is the Barumun River, located in South Labuhanbatu District, North Sumatra Province. Barumun River originates from a spring in Siraisan, Padang Lawas District located in the southeastern part of the province. The river flows to the northern part through 3 districts, namely North Padang Lawas District, South Labuhanbatu District and Labuhan Batu District until reaches the eastern coast of Sumatra or an estuary in the Melaka Strait. Barumun River is recorded as the longest river in North Sumatra with a length of $440 \mathrm{~km}$. The local community is highly dependent on the rivers, especially as a source of fish for consumption and livelihood. Local fishes, such as baung (Hemibagus nemurus), belida (Chitala lopis), silais (Ompok hypophthalmus), and giant prawns (Macrobrachium rosenbergii) are notable freshwater species that are preserved through a good and 
sustainable river ecosystem management.

One primary feature in the field of watershed ecology is the presence of riparian vegetation that is able to support the life of the ecosystem communities. According to Haryadi et al. (2019), habitat degradation and alteration affect the structure of the ecosystem including the native vegetation within, so it is necessary to monitor the changes that occur. In the context of Barumun River, the conversion of land into plantation areas such as oil palm (Elaeis guineensis) and seasonal crop farming such as cucumber (Cucumis sativus), cowpea (Vigna unguiculata), and smooth pigweed (Amaranthus hybridus), are potential threats to the sustainability of the watershed and its surrounding ecosystem in the Labuhanbatu District as documented from the biodiversity monitoring of its benthic organisms (Harahap et al. 2018; Harahap et al. 2021). Ideally, tree vegetation should dominate the riparian to support the sustainability of the river ecosystem. This research aimed to investigate the diversity, structure and composition of vegetation in the Barumun River including its smaller streams (rivulets). This study provides the current state of the vegetation in the Barumun watershed for the management of the freshwater region and can serve as baseline information for future studies to monitor the watershed changes.

\section{MATERIALS AND METHODS}

\section{Study period and area}

Vegetation survey was conducted from June to November 2020. The research sites were located along the streams of Barumun Watershed, South Labuhanbatu District, North Sumatra, Indonesia (Figure 1). The sampling was conducted systematically following the mainstream of Barumun River (Station 1) through the two rivulets namely Tasik Rivulet (Station 2) and Titi Kembar Rivulet (Station 3).

\section{Data collection}

Data on vegetation were collected using a combination method between line transect and quadratic plots placed at each river side (Simon 2007). The total number of observation plots was 48 plots consisting of 24 plots of Barumun River, 12 plots of Tasik Rivulet and 12 plots of Titi Kembar Rivulet. The plant species were recorded for each community structure present in the sampling sites, i.e trees, poles, saplings, and seedlings based on the classification by Wyatt-Smith (1963).

The classification for each structure is defined as follows: tree having a diameter at breast height $(\mathrm{DBH})>20$ $\mathrm{cm}$, pole with $10 \geq \mathrm{DBH}>20 \mathrm{~cm}$, sapling with a height $>1.5$ $\mathrm{m}$, seedling with a height less than $1.5 \mathrm{~m}$, and shrub with multiple woody stems and a height less than $5 \mathrm{~m}$. The plots were conditioned for each structure, i.e. $20 \times 20 \mathrm{~m}^{2}$ for trees, $10 \times 10 \mathrm{~m}^{2}$ for poles, $5 \times 5 \mathrm{~m}^{2}$ for saplings and shrubs, and $2 \times 2 \mathrm{~m}^{2}$ for seedlings. Plant species were identified using a collection of identification guides (Whitmore 1973; Whitmore 1978; Soerianegara and Lemmens 1994; Lemmens et al. 1995; Balgooy et al. 2015).
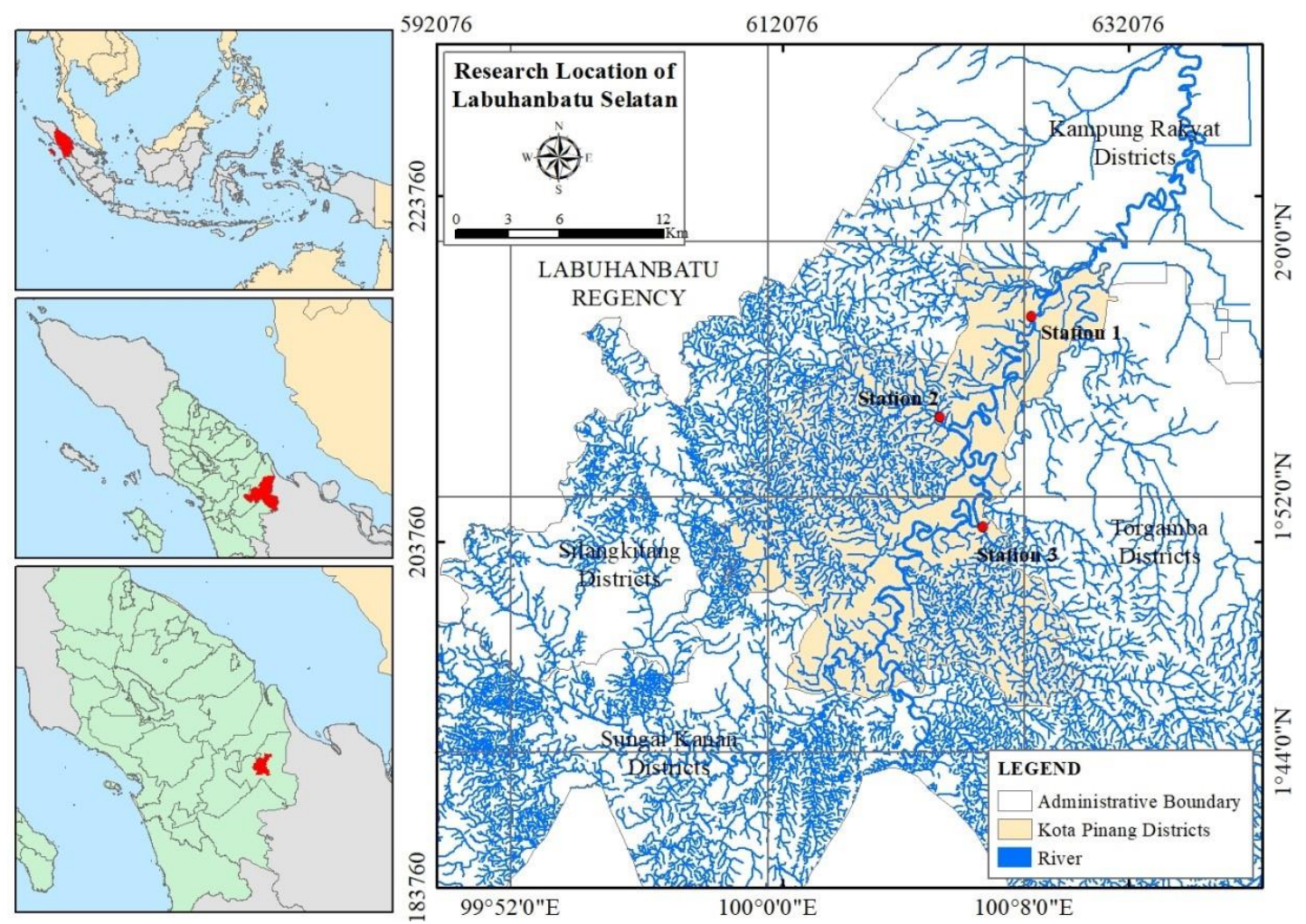

Figure 1. Map of study area showing the sampling sites (thick blue line) for riparian vegetation at Barumun Watershed, South Labuhanbatu District, North Sumatra, Indonesia 


\section{Data analysis}

Ecological parameters were analyzed including importance value index (IVI) obtained from the sum of relative density $(\mathrm{RD})$, relative frequency $(\mathrm{RF})$, and relative dominance (RD) or basal area for tree and pole class and without RD for sapling and seedling levels. Species diversity of each stage was measured using the following equation:

$$
\text { Shanno } n^{s} s \text { diversity index }\left(H^{s}\right)=-\sum_{i=1}^{s} p i \ln p i
$$

Where, $p$ is the proportion of $(n / N)$ of individuals of a certain plant species $(n)$ divided by the total number of individuals $(N)$. In is a natural logarithmic value, $\Sigma$ is the sum of calculations while $s$ is the number of species. The level of species diversity is classified as high $\left(H^{\prime}>3\right)$, moderate $\left(1 \leq H^{\prime} \leq 3\right)$, and low $\left(H^{\prime}<1\right)$ (Odum 1996). Margalef's species richness was calculated using the formula (Magurran 1988):

$$
D_{\mathrm{mg}}=\frac{S-1}{\operatorname{Ln} N}
$$

Where, $D_{m g}$ is Margalef's species richness index, $S$ is the number of documented species. $N$ is the total number of individuals and $\ln$ is a natural logarithmic value. The level of species richness is classified as high $\left(D_{m g}>5\right)$, moderate $\left(3.5 \leq D_{m g} \leq 5\right)$, and low $\left(D_{m g}<3.5\right)$. Species evenness is a measure of the relative abundance of the different species in an area. The index was determined using the following equation:

$$
I^{f}=\frac{H^{y}}{H_{\max }}
$$

Where, $H^{\prime}$ is Shannon's diversity index of a study site, $H_{\text {max }}$ is the natural logarithmic value of $S$ (species richness).

\section{RESULTS AND DISCUSSION}

\section{Species composition of riparian vegetation in Barumun Watershed}

The results documented a total of 51 plant species in the Barumun Watershed in which 37 species were found in the Barumun River, 20 species in the Tasik Rivulet, and 17 species in the Titi Kembar Rivulet. Plant species consisted of several habitus such as herbs, palms, shrubs, climbers and trees. The trees were composed of 22 species (43.13\%), herbs with 22 species $(43.13 \%)$, climbers with 3 species $(5.88 \%)$, shrubs with 2 species $(3.92 \%)$, and palms with 2 species $(3.92 \%)$. There were 42 species of wild plants $(82.35 \%)$ and 9 species of cultivated plants (17.64\%). The presence of wild plant species around Barumun Watershed must be preserved as the local timber species in protecting the watershed. The species composition of riparian vegetation collected in the Barumun Watershed is presented in Table 1.
The plant species recorded in all observation sites were Elaeis guineensis, Nephrolepis biserrata, Cayratia trifolia, Stenochlaena palustris, and Swietenia mahagoni. Elaeis guineensis Jacq. (oil palm) was not considered the native plant species but commodity plant deliberately cultivated by the local community. Oil palm is a tropical plant that is thought to have originated from Nigeria (West Africa). Oil palm is an important oil-producing crop in the tropical region that can also be used as a raw material for the food and non-food industries (Herdiansyah et al. 2020). On the banks of the Barumun River, the oil palm plantations maintained by the local community are one of the primary resources of livelihood of the community. It was not surprising that the current expansion of oil palm in the Barumun Watershed may become the potential driving force of deforestation to the riparian community in the future.

Nephrolepis biserrata (Davalliaceae) is a fern species also known as gray nails. The fern was the most commonly found species around the Barumun River which may be regarded as a cosmopolite species. A study by Riastuti et al. (2018) also reported the presence of Nephrolepis biserrata in the Lake Aur, Musi District, Indonesia. Cayratia trifolia (Vitaceae) is one of the wild plants mostly found in the Southeast Asia region, including Indonesia with tendrils to grow as a climber plant (Prasetyo et al. 2016). Stenochlaena palustris (Blechnaceae) is a fern species that thrives on peat and sandy soils (Adawiyah and Rizki 2018). Swietenia mahagoni (Meliaceae) is a wellknown timber species in Indonesia. The mahogany trees documented around the Barumun Watershed were also deliberately planted by the Forestry Service in order to reforest the riverbank.

\section{Importance Value Index (IVI) of the vegetation structure in Barumun Watershed}

Important Value Index (IVI) is used to rank species based on their ecological importance. This indicator is used to determine the dominant species at each growth stage in a particular community (Susilowati et al. 2020). Smith (1977) stated that the dominant species is a species that can utilize its environment efficiently from other species in the same place. The IVI from each stage from trees, poles, saplings, seedlings, and shrubs are presented in Tables 2-6. The highest IVI for tree species at Barumun River was Hevea brasiliensis (108.28) while at Titi Kembar Rivulet was Cryptocarya sp. (123.24). There was no record of tree species at Tasik Rivulet (Table 2). Muntingia calabura had the highest IVI for pole stage at Tasik Rivulet and Barumun River with 170.37 and 170.37, respectively while Swietenia mahagoni had the highest IVI at Titi Kembar Rivulet with 150.92 (Table 3). The highest IVI for sapling stage was Nauclea orientalis (200) at Tasik Rivulet, Bridelia tomentosa (87.00) at Titi Kembar Rivulet, and Tilia tomentosa (49.57) at Barumun River (Table 4). The highest IVI for seedling species was Psychotria viridiflora (158.33) at Tasik Rivulet, Hibiscus tiliaceus (94.44) at Barumun River, and Bridelia tomentosa (61.58) at Titi Kembar Rivulet. The highest IVI for shrub species was Calamus axillaris (62.70) at Titi Kembar Rivulet, Axonopus compressus (40.45) at Barumun River, and Elaeis guineensis (37.07) at Tasik River (Table 6). 
Table 1. Species list and composition of riparian vegetation around the Barumun Watershed, South Labuhanbatu District, North Sumatra, Indonesia

\begin{tabular}{|c|c|c|c|c|c|c|c|}
\hline Local name & Scientific name & Family & $\begin{array}{c}\text { Station } \\
1 \\
\end{array}$ & $\begin{array}{c}\text { Station } \\
2 \\
\end{array}$ & $\begin{array}{c}\text { Station } \\
\mathbf{3} \\
\end{array}$ & Habitus & $\begin{array}{c}\begin{array}{c}\text { Growth } \\
\text { mode }\end{array} \\
\end{array}$ \\
\hline Gelagah & Saccharum spontaneum & Poaceae & + & + & - & Herb & Wild \\
\hline Rumput manis & Axonopus compressus & Poaceae & + & + & - & Herb & Wild \\
\hline Pakis kawat & Gleichenia Linearis & Gleicheniaceae & + & - & - & Herb & Wild \\
\hline Pakis makan & Diplazium esculentum & Athyriaceae & + & - & - & Herb & Wild \\
\hline Sawit & Elaeis guineensis & Arecaceae & + & + & + & Palm & Cultivated \\
\hline Panggu & Saccharum revennae & Poaceae & + & + & & Herb & Wild \\
\hline Pakis liar & Nephrolepis biserrata & Nephrolepidaceae & + & + & + & Herb & Wild \\
\hline Syngonium & Syngonium podophyllum & Araceae & + & + & & Herb & Wild \\
\hline Rumput rambatan & Mikania micrantha & Asteraceae & + & - & - & Herb & Wild \\
\hline Rumput kawat & Thuarea involute & Poaceae & + & + & & Herb & Wild \\
\hline Andor anggur & Cayratia trifolia & Vitaceae & + & + & + & Climber & Wild \\
\hline Paria gunung & Cardiospermum halicacabum & Sapindaceae & + & + & - & Herb & Wild \\
\hline Kelapa & Cocos nucifera & Arecaceae & + & - & - & Palm & Cultivated \\
\hline Rumput anting & Acalypha indica & Euphorbiaceae & + & - & - & Herb & Wild \\
\hline Bambu kuning & Bambusa vulgaris var. striata & Poaceae & + & - & - & Herb & Cultivated \\
\hline Rumput teki & Cyperus rotundus & Cyperaceae & + & - & - & Herb & Wild \\
\hline Rumput Israel & Justicia Gangetica & Acanthaceae & + & + & - & Herb & Wild \\
\hline Senduduk bulu & Clidemia hirta & Melastomataceae & + & - & - & Shrub & Wild \\
\hline Tubari & Derris elliptica & Fabaceae & + & - & - & Climber & Wild \\
\hline Babadotan & Ageratum conyzoides & Asteraceae & + & - & - & Herb & Wild \\
\hline Pakis Pucuk merah & Stenochlaena palustris & Blechnaceae & + & + & + & Herb & Wild \\
\hline Rumput Israel & Asystasia gangetica & Acanthaceae & + & - & - & Herb & Wild \\
\hline Meniran & Phyllanthus niruri & Phyllanthaceae & + & - & - & Herb & Wild \\
\hline Sidaguri & Sida Rhombifolia & Malvaceae & + & - & - & Herb & Wild \\
\hline Puri malu & Mimosa pudica & Fabaceae & - & + & - & Herb & Wild \\
\hline Duri & Leucaena sp & Fabaceae & - & + & - & Shrubs & Wild \\
\hline Pangkat & Calamus sp & Arecaceae & - & + & + & Climbers & Wild \\
\hline Uppe & Saccharum sp & Poaceae & - & + & + & Herb & Wild \\
\hline Bambu & Bambusa sp & Poaceae & - & - & + & Herb & Wild \\
\hline Hatinar & Tilia tomentosa & Malvaceae & + & - & - & Tree & Wild \\
\hline Waru & Hibiscus tiliaceus & Malvaceae & + & - & - & Tree & Wild \\
\hline Jambu & Psidium guajava & Myrtaceae & + & - & - & Tree & Cultivated \\
\hline Sikkam & Bischovia javanica & Phyllanthaceae & + & - & - & Tree & Wild \\
\hline Mahoni & Swietenia mahagoni & Meliaceae & + & + & + & Tree & Cultivated \\
\hline Cia & Elaeagnus angustifolia & Elaeagnaceae & + & - & - & Tree & Wild \\
\hline Mangga & Mangifera indica & Anacardiaceae & + & - & - & Tree & Cultivated \\
\hline Ikan-ikan & Bridelia tomentosa & Phyllanthaceae & + & - & + & Tree & Wild \\
\hline Kepadan & Grewia picta & Tiliciae & + & - & + & Tree & Wild \\
\hline Seri & Muntingia calabura & Muntingiaceae & + & + & - & Tree & Wild \\
\hline Karet & Hevea brasilensis & Euphorbiaceae & + & - & + & Tree & Cultivated \\
\hline Gala-gala & Ficus racemosa & Moraceae & + & - & + & Tree & Wild \\
\hline Jati & Gmelina arborea & Verbenaceae & + & - & - & Tree & Cultivated \\
\hline Kapas & Gossypium hirsutum & Malvaceae & + & - & - & Tree & Wild \\
\hline Jambu manik & Syzygium buxifolium & Myrtaceae & - & - & + & Tree & Wild \\
\hline Duri-duri & Leucaena $s p$ & Fabaceae & - & - & + & Tree & Wild \\
\hline Cikaok & Cryptocarya sp & Lauraceae & - & - & + & Tree & Wild \\
\hline Beringin & Ficus benjamina & Moraceae & - & - & + & Tree & Wild \\
\hline Rambai & Baccaurea motleyana & Phyllanthaceae & - & - & + & Tree & Wild \\
\hline Salung-salung & Psychotria viridiflora & Rubiaceae & - & + & - & Tree & Wild \\
\hline- & Croton argyratus & Euphorbiaceae & - & + & - & Tree & Wild \\
\hline Longkidae & Nauclea orientalis & Rubiaceae & - & + & - & Tree & Cultivated \\
\hline Total & & & 37 & 20 & 17 & & \\
\hline
\end{tabular}


Table 2. Importance Value Index (IVI) of tree stage in Barumun Watershed, South Labuhanbatu District, North Sumatra, Indonesia

\begin{tabular}{|c|c|c|c|c|}
\hline Species & Relative density & Relative frequency & Relative basal area & IVI \\
\hline \multicolumn{5}{|l|}{ Barumun River } \\
\hline Hevea brasiliensis & 47.62 & 12.50 & 48.16 & 108.28 \\
\hline Muntingia calabura & 23.81 & 12.50 & 13.38 & 49.69 \\
\hline Hibiscus tiliaceus & 9.52 & 25.00 & 11.10 & 45.63 \\
\hline Ficus racemosa & 9.52 & 25.00 & 16.72 & 51.25 \\
\hline Gmelina arborea & 4.76 & 12.50 & 4.70 & 21.97 \\
\hline Gossypium hirsutum & 4.76 & 12.50 & 5.92 & 23.19 \\
\hline \multicolumn{5}{|l|}{ Titi Kembar Rivulet } \\
\hline Cryptocarya $\mathrm{sp}$ & 44.44 & 37.50 & 41.29 & 123.24 \\
\hline Ficus benjamina & 22.22 & 25.00 & 16.67 & 63.89 \\
\hline Hevea brasiliensis & 11.11 & 12.50 & 10.20 & 33.81 \\
\hline Baccaurea motleyana & 11.11 & 12.50 & 11.94 & 35.55 \\
\hline Anthocephalus cadamba & 11.11 & 12.50 & 19.90 & 43.51 \\
\hline
\end{tabular}

Table 3. Importance Value Index (IVI) of pole stage in Barumun Watershed, South Labuhanbatu District, North Sumatra, Indonesia

\begin{tabular}{|c|c|c|c|c|}
\hline Species & Relative density & Relative frequency & Relative basal area & IVI \\
\hline \multicolumn{5}{|l|}{ Barumun River } \\
\hline Muntingia calabura & 50.00 & 50.00 & 70.37 & 170.37 \\
\hline Swietenia mahagoni & 50.00 & 50.00 & 29.63 & 129.63 \\
\hline \multicolumn{5}{|l|}{ Titi Kembar Rivulet } \\
\hline Swietenia mahagoni & 42.86 & 40.00 & 68.06 & 150.92 \\
\hline Cryptocarya sp & 42.86 & 40.00 & 9.68 & 92.54 \\
\hline Ficus racemosa & 14.29 & 20.00 & 22.26 & 56.55 \\
\hline \multicolumn{5}{|l|}{ Tasik Rivulet } \\
\hline Muntingia calabura & 77.78 & 50.00 & 2.21 & 226.88 \\
\hline Swietenia mahagoni & 22.22 & 50.00 & 0.02 & 73.12 \\
\hline
\end{tabular}

Table 4. Importance Value Index (IVI) of sapling stage in Barumun Watershed, South Labuhanbatu District, North Sumatra, Indonesia

\begin{tabular}{lccc}
\hline \multicolumn{1}{c}{ Species } & $\begin{array}{c}\text { Relative } \\
\text { density }\end{array}$ & $\begin{array}{c}\text { Relative } \\
\text { frequency }\end{array}$ & IVI \\
\hline Barumun River & & & \\
$\quad$ Tilia tomentosa & 38.46 & 11.11 & 49.57 \\
$\quad$ Eucalyptus alba & 15.38 & 22.22 & 37.61 \\
Bischovia javanica & 7.69 & 11.11 & 18.80 \\
$\quad$ Swietenia mahagoni & 7.69 & 11.11 & 18.80 \\
$\quad$ Elaeagnus angustifolia & 7.69 & 11.11 & 18.80 \\
$\quad$ Mangifera indica & 7.69 & 11.11 & 18.80 \\
Bridelia tomentosa & 7.69 & 11.11 & 18.80 \\
$\quad \begin{array}{l}\text { Grewia picta } \\
\text { Titi Kembar Rivulet }\end{array}$ & 7.69 & 11.11 & 18.80 \\
$\quad$ Bridelia tomentosa & 50.01 & 40.00 & 87.00 \\
$\quad \begin{array}{l}\text { Ficus benjamina } \\
\text { Cryptocarya sp }\end{array}$ & 16.67 & 20.00 & 36.67 \\
$\quad \begin{array}{l}\text { Grewia picta } \\
\text { Tasik Rivulet }\end{array}$ & 16.67 & 20.00 & 36.67 \\
Nauclea orientalis & 16.67 & 20.00 & 36.67 \\
\hline & 100 & 100 & 200 \\
\hline
\end{tabular}

Table 5. Importance Value Index (IVI) of seedling stage in Barumun Watershed, South Labuhanbatu District, North Sumatra, Indonesia
Riparian trees are important factors to indicate the water quality of springs and their drains (Semiun et al., 2013). A high riparian tree diversity may be associated with high oxygen levels in rivers and streams, which serve as clean water resources (ecosystem service) for human and livestock (Luke et al. 2018). However, due to some

\begin{tabular}{lccc}
\hline \multicolumn{1}{c}{ Species } & $\begin{array}{c}\text { Relative } \\
\text { density }\end{array}$ & $\begin{array}{c}\text { Relative } \\
\text { frequency }\end{array}$ & IVI \\
\hline $\begin{array}{l}\text { Barumun River } \\
\text { Hibiscus tiliaceus }\end{array}$ & 50.00 & 44.44 & 94.44 \\
$\quad$ Psidium guajava & 30.00 & 33.33 & 63.33 \\
$\quad \begin{array}{l}\text { Tilia tomentosa } \\
\text { Titi Kembar Rivulet }\end{array}$ & 20.00 & 22.22 & 42.22 \\
$\quad$ Bridelia tomentosa & 31.58 & 30 & 61.58 \\
$\quad$ Leucaena sp & 26.32 & 20 & 46.32 \\
$\quad$ Hevea brasiliensis & 15.79 & 20 & 35.79 \\
$\quad$ Syzygium buxifolium & 15.79 & 10 & 25.79 \\
$\quad$ Cryptocarya sp & 5.26 & 10 & 15.26 \\
$\quad$ Ficus racemosa & 5.26 & 10 & 15.26 \\
Tasik Rivulet & & & \\
$\quad$ Psychotria viridiflora & 83.33 & 75 & 158.33 \\
$\quad$ Croton argyratus & 16.67 & 25 & 41.67 \\
\hline
\end{tabular}

concerning anthropogenic activities, the diversity of riparian vegetation is being threatened as documented in previous studies in human-altered sites (Izzati and Hasibuan 2019; Takarina et al. 2021). Rubber (Hevea brasiliensis) was documented as the highest IVI for tree stage in Barumun River. The dominant rubber tree 
(Euphorbiaceae) in the study area may be explained due to its adaptive trait by forming an early wide canopy and sturdy root system to obtain an optimum amount of water and soil nutrients (Bibiana et al. 2015). Hence, the species also survive under low sunlight intensity which then outcompeting the surrounding plant species. A study by Guardiola-Claramonte et al. (2010) also revealed that $H$. brasiliensis may dominate landscapes around catchment explaining their abundant presence in the riparian ecosystem. The phenology of rubber is affected by the high physiological demand of water, which may later replace native riparian vegetation. In addition, the rubber was also planted as industrial crops with the center of production in the North Sumatra, South Sumatra and Riau Province which also explained the distribution of this species in other adjacent and undisturbed areas (Hytonen et al. 2019). Meanwhile, the documentation of Cryptocarya sp. (Lauraceae) in our study was still limited compared to another region in the northern part of Sumatra. The species has been well documented in freshwater swamp forests, Riau (Lisdayanti et al. 2016), freshwater swamp forest, West Sumatra (Yusuf and Purwaningsih 2009), and riverine forest, Aceh (Sambas and Siregar 2004).

\section{Species diversity, richness, and evenness index of riparian vegetation around Barumun Watershed}

The Shannon diversity index in the study area was ranged between 0.38 (Titi Kembar Rivulet) to 2.26 (Tasik Rivulet) classified as low to moderate level of diversity. In general, low species diversity was recorded in all pole stages in the Barumun Watershed (0.38-0.69). The diversity index was quite stable in the Barumun River $(H$ ' $=0.69-2.24)$ and Titi Kembar Rivulet $\left(H^{\prime}=0.38-1.72\right)$ but not in Tasik Rivulet due to the absence of sapling and tree stage. Following a similar trend, the highest species richness or $D_{m g}$ in the study sites was recorded in Barumun
River (23.83), followed by Tasik Rivulet (16.82) and Titi Kembar Rivulet (6.50). All documented species richness belonged to the shrub structure. In addition, the level of species richness in the study area was categorized from low to high. The species evenness $\left(J^{\prime}\right)$ in the study area was noted for some dominance in the Titi Kembar Rivulet (0.35) for the pole structure while other sites such as in the Barumun River and Titi Kembar Rivulet showed a moderate to equal species distribution.

Table 6. Importance Value Index (IVI) of shrub stage in Barumun Watershed, South Labuhanbatu District, North Sumatra, Indonesia

\begin{tabular}{lccc}
\hline \multicolumn{1}{c}{ Species } & $\begin{array}{c}\text { Relative } \\
\text { Density }\end{array}$ & $\begin{array}{c}\text { Relative } \\
\text { Frequency }\end{array}$ & IVI \\
\hline Barumun River & & & \\
$\quad$ Axonopus compressus & 28.13 & 12.33 & 40.45 \\
$\quad$ Saccharum spontaneum & 18.55 & 17.81 & 36.36 \\
Elaeis guineensis & 18.16 & 17.81 & 35.97 \\
$\quad$ Saccharum sp & 7.81 & 8.22 & 16.03 \\
Titi Kembar Rivulet & & & \\
Calamus axillaris & 38.89 & 23.81 & 62.70 \\
Cayratia trifolia & 11.11 & 28.57 & 39.68 \\
Elaeis guineensis & 19.44 & 14.29 & 33.73 \\
Stenochlaena palustris & 11.11 & 14.29 & 25.40 \\
$\quad$ Saccharum sp & 9.26 & 4.76 & 14.02 \\
Nephrolepis biserrata & 4.63 & 4.76 & 10.00 \\
Thuarea involute & 4.63 & 4.76 & 10.00 \\
Tasik Rivulet & & & \\
Elaeis guineensis & 18.14 & 18.92 & 37.07 \\
Axonopus compressus & 23.16 & 5.41 & 28.57 \\
Cyperus rotundus & 12.74 & 12.74 & 20.85 \\
$\quad$ Saccharum sp & 7.72 & 10.81 & 18.53 \\
Saccharum revennae & 10.03 & 8.11 & 18.15 \\
Saccharum spontaneum & 5.40 & 10.81 & 16.22 \\
Nephrolepis biserrata & 9.65 & 2.70 & 12.36 \\
\hline
\end{tabular}

Table 7. Shannon's diversity index, Margalef's species richness, and evenness index of the riparian community structure in the Barumun Watershed, South Labuhanbatu District, North Sumatra, Indonesia

\begin{tabular}{lcccccc}
\hline \multicolumn{1}{c}{ Structure } & $\begin{array}{c}\text { Shannon's Diversity } \\
\text { Index }\left(\boldsymbol{H}^{\prime}\right)\end{array}$ & Category & $\begin{array}{c}\text { Margalef's } \\
\text { species richness }\left(\boldsymbol{D}_{\boldsymbol{m g}}\right)\end{array}$ & Category & $\begin{array}{c}\text { Evenness Index } \\
\left(\boldsymbol{J}^{\prime}\right)\end{array}$ & Category \\
\hline Barumun River & & & & & \\
Shrub & 2.24 & Moderate & 23.83 & High & 0.70 & Moderate \\
Seedling & 1.03 & Moderate & 2.56 & Low & 0.93 & Equal \\
Sapling & 1.84 & Moderate & 7.51 & High & 0.88 & Moderate \\
Pole & 0.69 & Low & 1.27 & Low & 0.99 & Equal \\
Tree & 1.43 & Moderate & 5.67 & High & 0.79 & Moderate \\
Titi Kembar Rivulet & & & & & \\
Shrub & 1.72 & Moderate & 6.50 & High & 0.78 & Moderate \\
Seedling & 1.60 & Moderate & 5.66 & High & 0.89 & Moderate \\
Sapling & 1.49 & Moderate & 4.41 & Moderate & 0.92 & Equal \\
Pole & 0.38 & Low & 2.48 & Low & 0.35 & Dominance \\
Tree & 1.42 & Moderate & 4.54 & Moderate & 0.88 & Moderate \\
Tasik Rivulet & & & & & \\
Shrub & 2.26 & Moderate & 16.82 & High & 0.79 & Moderate \\
Seedling & 0.45 & Low & 1.44 & Low & 0.65 & Moderate \\
Sapling & - & Low & 0.63 & Low & - & - \\
Pole & 0.53 & Low & 1.54 & Low & 0.76 & Moderate \\
Tree & - & - & - & - & - \\
\hline
\end{tabular}


In conclusion, our study documented a total of 51 plant species at three studied sites in the Barumun Watershed, South Labuhanbatu District with details of 37 species at the Barumun River, 20 species at the Tasik Rivulet, and 17 species at the Titi Kembar Rivulet. The habitus recorded among all species were herbs, palms, shrubs, climbers and trees. The composition of tree habitus was 22 species (43.13\%), herbs with 22 species (43.13\%), climbers with 3 species $(5.88 \%)$, shrubs with 2 species $(3.92 \%)$, and palms with 2 species $(3.92 \%)$. The presence of the timber species around Barumun Watershed must be preserved in order to protect the hydrological function of the riverbanks.

\section{ACKNOWLEDGEMENTS}

This research was fully funded by University of Sumatera Utara through TALENTA research grant with the contract number: 63/UN5.2.3.1/PPM/SPP-TALENTA USU/2020. We also thank the local government and fishermen in North Labuhanbatu, Indonesia who supported us during this research in the field.

\section{REFERENCES}

Adawiyah R, Rizki MI. 2018. Aktivitas antioksidan ekstrak etanol akar Kalakai (Stenochlaena palustris Bedd) asal Kalimantan Tengah. Jurnal Pharmascience 5 (1): 71-77. DOI: 10.20527/jps.v5i1.5788. [Indonesian]

Balgooy MMJV, Low YW, Wong KM. 2015. Spot Characters for the Identification of Malesian Seed Plants: A Guide. Natural History Publications, Borneo.

Basrowi M, Hendra M, Hariani N. 2018. Komposisi dan struktur pohon riparian di Sungai Kahala Kabupaten Kutai Kartanegara. Jurnal Pro Life 5 (3): 637-649. [Indonesian]

Bibiana A, Burhannudin, Iswan D. 2015. Struktur dan komposisi vegetasi di areal petak ukur permanen (PUP) PT. Kawedar Wood Industry Kabupaten Kapuas Hulu. Jurnal Hutan Lestari 3 (1): 150-159. [Indonesian]

Guardiola-Claramonte M, Troch PA, Ziegler AD, Giambelluca TW, Durcik M, Vogler JB, Nullet MA. 2010. Hydrologic effects of the expansion of rubber (Hevea brasiliensis) in a tropical catchment. Ecohydrology 3 (3): 306-314. DOI: 10.1002/eco.110.

Halengkara L, Gunawan T, Purnama S. 2012. Analisis kerusakan lahan untuk pengelolaan daerah aliran sungai melalui integrasi teknik penginderaanjauh dan sistem informasi geografis. Majalah Geografi Indonesia 26 (2): 149-173. [Indonesian]

Harahap A, Barus TA, Mulya MB, Ilyas S. 2018. Macrozoobenthos diversity as bioindicator of water quality in the Bilah River, Rantauprapat. J Phys Conf Ser 1116 (5): 052026. DOI: 10.1088/1742 $6596 / 1116 / 5 / 052026$

Harahap A, Mahadewi EP, Ahmadi D, Tj HW, Ganiem LM, Rafika M, Hartanto A. 2021. Monitoring of macroinvertebrates along streams of Bilah River, North Sumatra, Indonesia. Intl J Conserv Sci 12 (1): $247-$ 258.

Haryadi, Sunarto, Sugiyarto. 2019. Vegetation analysis of the secondary forest area in Cangkringan Resort, Mount Merapi National Park. Jurnal Biodjati 4 (1): 50-57. DOI: 10.15575/biodjati.v4i1.4239

Herdiansyah H, Negoro HA, Rusdayanti N, Shara S. 2020. Palm oil plantation and cultivation: Prosperity and productivity of smallholders. Open Agric 5 (1): 617-630. DOI: 10.1515/opag-20200063
Hytonen J, Nurmi J, Kaakkurivaara N, Kaakurivaara T. 2019. Rubber tree (Hevea brasiliensis) biomass, nutrient content, and heating values in Southern Thailand. Forest 10: 638. DOI: 10.3390/f10080638

Indriyanto. 2006. Ekologi Hutan. PT Bumi Aksara, Jakarta. [Indonesian]

Izzati U, Hasibuan HS. 2019. Riparian tree and bird diversity in Cisadane River, South Tangerang City, Indonesia. Biodiversitas 20 (2): 595603. DOI: $10.13057 /$ biodiv/d200241.

Lemmens RHMJ, Soerianegara I, Wong WC. 1995. Plant Resources of South-East Asia No. 5 (2) Timber Trees: Minor Commercial Timbers. Prosea Foundations, Bogor.

Lisdayanti, Hikmat A, Istomo. 2016. Komposisi flora dan keragaman tumbuhan di hutan rawa musiman, Rimbo Tujuh Danau Riau. Jurnal Penelitian Hutan dan Konservasi Alam 3 (1): 15-28. [Indonesian]

Liu L, Gudmundsson L, Hauser M, Qin D, Li S, Seneviratne SI. 2020. Soil moisture dominates dryness stress on ecosystem production globally. Nature 11: 4892. DOI: 10.1038/s41467-020-18631-1

Luke SH, Slade EM, Gray CL, Annammala KV, Drewer J, Williamson J, Agama AL, Ationg M, Mitchell SL, Vairappan CS, Struebig MJ. 2019. Riparian buffers in tropical agriculture: Scientific support, effectiveness and directions for policy. J Appl Ecol 56 (1): 85-92. DOI: $10.1111 / 1365-2664.13280$

Magurran AE. 1988. Ecological Diversity and Its Measurement. Princeton University Press, Princeton.

Odum EP. 1996. Dasar-dasar Ekologi. Gadjah Mada University Press, Yogyakarta. [Indonesian]

Piao S, Yin G, Tan J, Cheng L, Huang M, Li Y, Liu R, Mao J, Myneni RB, Peng S, Poulter B, Shi X, Xiao Z, Zeng N, Wang Y. 2015. Detection and attribution of vegetation greening trend in China over the last 30 years. Glob Change Biol 21 (4): 1601-1609. DOI: 10.1111/gcb.12795

Prasetyo B, Linda R, Mukarlina. 2016. Pemanfaatan tumbuhan lakum (Cayratia trifolia (L.) Domin.) oleh etnis Melayu di Kecamatan Sungai Kunyit Kabupaten Mempawah. Protobiont 5 (2): 25-33. DOI: 10.26418/protobiont.v5i2.15929. [Indonesian]

Riastuti RD, Sepriyaningsih S, Ernawati D. 2018. Identifikasi divisi pteridophyta di Kawasan Danau Aur Kabupaten Musi Rawas. Jurnal Pendidikan Biologi dan Sains 1 (1): 52-70. DOI: 10.31539/bioedusains.v1i1.253. [Indonesian]

Sambas EN, Siregar M. 2004. Flora of Alas River Bank, Ketambe, Gunung Leuser National Park. BioSmart 6 (1): 33-38.

Semiun CG, Arisoesilaningsih E, Retnaningdyah C. 2013. Degradation of riparian tree diversity on spring-fed drains and its impacts to water quality, East Java. J Trop Life Sci 3 (2): 120-126.

Simon H. 2007. Metode Inventore Hutan. Pustaka Pelajar, Yogyakarta. [Indonesian]

Smith RL. 1977. Elements of Ecology and Field Biology. Harper \& Row Publisher, New York.

Soerianegara I, Lemmens RHMJ. 1994. Plant Resources of South-East Asia No. 5(1) Timber Trees: Major Commercial Timbers. Prosea Foundations, Bogor.

Susilowati A, Elfiati D, Rachmat HH, Yulita KS, Hadi AN, Kusuma YS, Batu SAL. 2020. Vegetation structure and floristic composition of tree species in the habitat of Scaphium macropodum in Gunung Leuser National Park, Sumatra, Indonesia. Biodiversitas 21 (7): 30253033. DOI: $10.13057 /$ biodiv/d210720

Takarina ND, Sinaga IL, Kultsum TR. 2021. Riparian plant diversity in relation to artisanal mining sites in Cikidang River, Banten, Indonesia. Biodiversitas 22 (1): 401-407. DOI: 10.13057/biodiv/d220149

Tian F, Liu LZ, Yang JH, Wu JJ. 2021. Vegetation greening in more than 94\% of the Yellow River Basin (YRB) region in China during the 21 st century caused jointly by warming and anthropogenic activities. Ecol Indic 125: 107479. DOI: 10.1016/j.ecolind.2021.107479

Whitmore TC. 1973. Tree Flora of Malaya: A Manual for Foresters. Volume Two. Longman Malaysia SDN, Malaysia.

Whitmore TC. 1978. Tree Flora of Malaya: A Manual for Foresters. Volume Three. Longman Malaysia SDN, Malaysia.

Wyatt-Smith J. 1963. Manual of Malayan Silviculture for Inland Forest. Forest Research Institute Malaysia, Malaysia.

Yusuf R, Purwaningsih. 2009. Studi vegetasi hutan rawa air tawar di Cagar Alam Rimbo Panti, Sumatera Barat. Berita Biologi 9 (5): 491508. [Indonesian] 